\title{
Detection and Quantification of Phytophthora ramorum from California Forests Using a Real-Time Polymerase Chain Reaction Assay
}

\author{
Katherine J. Hayden, David Rizzo, Justin Tse, and Matteo Garbelotto
}

First, third, and fourth authors: Department of Environmental Science, Policy and Management, Ecosystem Science Division, University of California, Berkeley 94720; and second author: Department of Plant Pathology, University of California, Davis 95616. Accepted for publication 12 May 2004.

\begin{abstract}
Hayden, K. J., Rizzo, D., Tse, J., and Garbelotto, M. 2004. Detection and quantification of Phytophthora ramorum from California forests using a real-time polymerase chain reaction assay. Phytopathology 94:1075-1083.

The timely and accurate detection of pathogens is a critical aid in the study of the epidemiology and biology of plant diseases. In the case of regulated organisms, the availability of a sensitive and reliable assay is essential when trying to achieve early detection of the pathogen. We developed and tested a real-time, nested polymerase chain reaction (PCR) assay for the detection of Phytophthora ramorum, causal agent of sudden oak death. This technique then was implemented as part of a widespread

environmental screen throughout California. The method here described is sensitive, detecting less than $12 \mathrm{fg}$ of pathogen DNA, and is specific for $P$. ramorum when tested across 21 Phytophthora spp. Hundreds of symptomatic samples from 33 sites in 14 California counties were assayed, resulting in the discovery of 10 new host species and 23 infested areas, including 4 new counties. With the exception of a single host, PCRbased discovery of new hosts and infested areas always was confirmed by traditional pathogen isolations and inoculation studies. Nonetheless, molecular diagnostics were key in early pathogen detection, and steered the direction of further research on this newly discovered and generalist Phytophthora species.
\end{abstract}

Phytophthora ramorum is the causal agent for the disease commonly called sudden oak death (SOD). Although the disease is popularly known for its lethal, girdling cankers on susceptible oak species, the pathogen also causes less dramatic foliar symptoms on a wide - and ever-increasing — range of woody and herbaceous hosts $(14,21,22,33)$. P. ramorum first was identified on European Rhododendron and Viburnum spp. in 1993 (45), and then confirmed as the causal organism for SOD in California in 2000 (39). At the time of discovery, the known host list for $P$. ramorum in California included only two oak species, Quercus agrifolia and Q. kellogii, and tanoak, Lithocarpus densiflora. Confirmed isolations of the pathogen originated exclusively from woodlands in Marin County, CA. In Europe, confirmed isolations originated from a few horticultural nurseries in Germany and the Netherlands on Rhododendron and Viburnum spp. (45). Since then, a widespread environmental screening in the United States has expanded the confirmed host list to 30 species in 12 California counties, and to Curry County in southern Oregon $(43,44)$. Nurseries in many European countries are known to be infested $(10,26,32,35)$. Infested nurseries have been reported in the United States in California, Washington State, and Oregon, and in British Columbia, Canada (9). Infestations have been recently found in several states in the eastern United States. For an update on the current situation, see the U.S. Department of Agriculture (USDA)APHIS Pest Detection and Management Programs Sudden Oak Death website (44).

European and North American populations of the pathogen represent distinct lineages $(4,23)$ and are distinguishable by a range of phenotypic traits (4). European isolates tend to be faster

Corresponding author: M. Garbelotto; E-mail address: matteo@nature.berkeley.edu

Publication no. P-2004-0729-01R

(c) 2004 The American Phytopathological Society growing, and almost all are of mating type A1 $(4,46)$. North American isolates have been observed to have broader sporangia and variable growth rates (D. Hüberli, personal communication), and populations in the wild all have been mating type A2 (D. Hüberli, personal communication). However, both A1 and A2 mating types have been reported in nurseries in Oregon, Washington, and British Columbia $(19,23)$.

Disease symptoms are reviewed in Davidson et al. (9). They include cankers, which often bleed viscous bark exudates, above the soil line in Quercus spp. and L. densiflora (39); and leaf blight, often associated with twig and branch dieback, in $L$. densiflora and all other hosts (13). Quercus spp. show trunk cankers alone, without foliar lesions. Species including maple (Acer macrophyllum), buckeye (Aesculus californica), and California bay laurel (Umbellularia californica) develop foliar lesions exclusively. Other species, including Rhododendron spp., manzanita (Arctostaphylos manzanita), and Pacific madrone (Arbutus menziesii), exhibit both foliar lesions and twig dieback. L. densiflora, in contrast, develops trunk cankers as well as both twig and foliar lesions (9). The disease has caused massive die-off of oak and tanoak trees in some areas, leaving up to $90 \%$ of adult tanoak and $40 \%$ of adult coast live oak dead in a stand (38). Species susceptible to foliar infections, rather than oak, now are believed to be responsible for most of the sporulation and spread of the pathogen in nature. Bay laurel, for instance, is the plant species on which infection and sporulation is most abundant in California $(13,38)$. There is great concern about the potential devastating effect of $P$. ramorum if moved into noninfested areas. Greenhouse trials have shown that important plant species, native to other parts of the world, are highly susceptible to this pathogen $(20,30,36,40,42)$. A range of nursery plants have proven to be susceptible to infection by $P$. ramorum $(40,45)$ and, consequently, all transport of confirmed hosts from infested U.S. counties is now regulated $(43,44)$. The effectiveness of this kind of regulation and quarantine depends on reliable detection of the pathogen. 
Traditionally, morphological identification has been the preferred method for detection of pathogenic microbes. However, morphological identification can pose a number of difficulties. Phytophthora spp., like many other microorganisms, may not always be culturable. Further, Phytophthora morphology may be plastic $(3,11)$, and distinguishing characteristics can be subtle (12). P. ramorum has been described only recently (45), and much of its phenotypic variability may remain uncharacterized. Additionally, successful isolations require host-specific protocols. For example, leaves of Pacific madrone must be cultured within 40 to 60 days of infection, whereas tanoak leaves must be soaked in water for up to 10 days before isolations may be obtained (D. Rizzo, unpublished data). The expanding host list, variable symptoms by host, plasticity in colony morphology, and variable success in culturing result in the need for a sensitive and reliable method of detection that is not strictly dependent on our ability to isolate or morphologically identify the pathogen.

The polymerase chain reaction (PCR) has long been used to detect pathogens that may not be cultured, such as viruses (47) and phytoplasmas $(18,27)$. Taxon-specific PCR has been used as a method of screening for microbes such as mycorrhizal fungi (16) as well as plant pathogens including other Phytophthora spp. $(2,24)$. Because specific primers are used to discern small amounts of microbial nucleic acids from a much larger quantity of host plant DNA, or because samples at times include PCR inhibitors, nested PCR may be required to detect low levels of infection $(1,2,17)$.

Successful primer design for detection of a pathogen requires that the target region be (i) unique to the organism of interest and (ii) conserved across populations of the organism of interest. The internal transcribed spacer (ITS) region has been shown to be largely conserved within Phytophthora spp. but differ across species $(7,28)$. Phylogenies subsequent to that of Cooke et al. (7) based on alternate gene regions largely gave upheld the groupings in the ITS-based phylogeny $(23,31)$. Because the ITS sequence occurs in multiple copies in the genome, the target concentration is effectively increased, thereby increasing its value for diagnostic primers. Most importantly, sequence information is available in this region for nearly all known species of Phytophthora (7). The species most similar to $P$. ramorum in the ITS region are $P$. lateralis (differing by $11 \mathrm{bp}$ ) and $P$. hibernalis (differing by $39 \mathrm{bp}$ ). Consequently, we designed $P$. ramorum-specific primers within the ITS region.

The current technique has the further advantage of being able to be performed as real-time PCR, visualized using an intercalating dye such as SYBR green. Real-time PCR allows products to be distinguished based not only on size but also on sequence, because melt temperatures will differ for same-sized but distinct products $(37,41)$. Multiplex PCR with universal primers may be used as a positive control, to indicate whether an observed negative is a true PCR-negative, or is the result of a failed extraction $(14,49)$.

An objective of the study was to develop a nested PCR-based assay to detect $P$. ramorum from DNA extracted directly from symptomatic tissue of putative hosts. The assay was used in a statewide survey to identify new infested areas as well as new plant hosts. The results reported here include information gleaned from that survey, as well as data on the PCR assay's specificity, sensitivity by host substrate and by season, and its potential use for pathogen DNA quantification.

\section{MATERIALS AND METHODS}

Statewide disease survey. The isolation of $P$. ramorum in July 2000 from dying tanoak and oak trees in central California (39) prompted the beginning of a statewide survey to determine the extent of the distribution of the pathogen. The survey, still ongoing in 2004, covers the entire geographic range of woodlands in California. It was initiated before the formal description of the pathogen, and at a time when our understanding of disease symptoms and of the pathogen host range was extremely limited. Thus, sites were examined not only for the presence of known $P$. ramorum symptoms on confirmed hosts, but also for the presence of unusual disease symptoms on any plant species. At each survey site, symptoms were described, locations of symptomatic trees were mapped, and symptomatic tissue was collected for cultural and PCR-based diagnoses, as described below. Symptomatic tissue was cultured by plating a small section from the margins of leaf or branch lesions or stem cankers on PARP selective medium (per liter: $17 \mathrm{~g}$ of corn meal agar, $0.25 \mathrm{~g}$ of ampicillin, $0.4 \mathrm{ml}$ of $2.5 \%$ Pimaricin, $0.01 \mathrm{~g}$ of Rifampicin in $1 \mathrm{ml}$ of dimethyl sulfoxide, $5 \mathrm{ml}$ of $0.5 \%$ pentachloronitrobenzene in ethanol). For DNA analyses, a comparable portion of symptomatic tissue was sealed in plastic bags or polypropylene tubes and stored at $10^{\circ} \mathrm{C}$ for a maximum of 4 days. Samples then were excised from the margins of necrotic areas with a scalpel and transferred to a 2.0-ml polypropylene tube, frozen, and lyophilized.

At times, diagnosis was ambiguous (e.g., no P. ramorum culture could be obtained from symptomatic plant tissue that had shown positive results using the PCR-based technique described here). In these cases, plants were sampled again and isolations were repeated, often modifying the original isolation techniques either by pretreatment of the tissue, such as by soaking the sample for an extended period of time, or by better selection of the tissue to be plated.

An excess of 2,000 samples were processed in the course of the survey by PCR-based methods and by culturing. Because the PCR protocol changed during the course of the survey, and because PCR-based results were consistently in agreement with those obtained through culturing, with a few exceptions (described below), here we report only on samples collected between May 2001 and August 2002. Samples collected within this time frame all were processed according to the methods described in this article.

The frequency of successful $P$. ramorum detection was determined for a total of 528 samples, composing all plant substrates tested in the survey. To take into account the effect of season, samples were grouped by collection date according to rainfall records into three categories, which represent distinct climatic periods: March to June (intermediate rainfall, following months of heavy rains, warm temperatures), July to October (little or no precipitation, hot temperatures), and November to February (heavy rains following the dry season, cold temperatures) $(5,6)$. Based on the current understanding of the biology of $P$. ramorum, prolonged rain events and warm temperatures like those normally recorded in the March-to-June period are optimal for infection and spread of the pathogen (38).

In order to compare efficacy of diagnosis by either culturing or PCR, a subset of 216 samples for which no culture initially was obtained was further screened by the PCR-based method described here, as well as by an additional round of isolations. Results of this analysis also were grouped by substrate, to compare the efficacy of the PCR method on samples taken from bay laurel leaves, leaves from hosts other than bay laurel, and oak and tanoak wood.

DNA extraction. Bulk DNA was extracted from lyophilized tissue using a modified cetyltrimethylammonium bromide (CTAB) extraction. Lyophilized tissue was pulverized with glass beads in a FastPrep instrument (Bio101, Carlsbad, CA) for 5 to $30 \mathrm{~s}$ at $4,000 \mathrm{rpm}$. Pulverized tissue was subjected to two repetitions of freezing (on dry ice for $2 \mathrm{~min}$ ) and thawing (at $75^{\circ} \mathrm{C}$ for $2 \mathrm{~min}$ ) in $350 \mu \mathrm{l}$ of CTAB. DNA was purified in phenol/chloroform/isoamyl alcohol (25:24:1), further cleaned by using the Geneclean Turbo Nucleic Acid Purification kit (Qiagen Inc., Valencia, CA) according to the manufacturer's instructions, and eluted in $30 \mu \mathrm{l}$ of ultrapure water (nanopurified, autoclaved, 
and UV irradiated). DNA extracts were stored at $-20^{\circ} \mathrm{C}$ in $1 / 10$ Tris-EDTA buffer. Extracts from mycelia were diluted 1/1,000 in ultrapure water prior to amplification, whereas extracts from plants were diluted 1/100.

Development of primers and PCR conditions. Two sets of specific primers (Table 1) were designed based on a manual revision of the Phytophthora spp. ITS alignment of Cooke et al. (7) to include $P$. ramorum. Primer3 software (version 0.6; available online from Whitehead Institute for Biomedical Research, Cambridge, MA) was used to select sites that were unique to $P$. ramorum, paying extra care to situate polymorphisms between $P$. ramorum and $P$. lateralis at the $3^{\prime}$ end of the Phyto1 and Phyto 4 primers. Phyto2 and Phyto3 were designed internal to Phyto1/ Phyto4; this pair is also specific to $P$. ramorum. Universal primers were designed in the conserved region of the $28 \mathrm{~S}$ rDNA sequence.

The first amplification was performed using primer set Phyto1/Phyto4. An aliquot of $6.25 \mu$ of diluted bulk DNA was included in each $25.00-\mu \mathrm{l}$ PCR reaction ( $1 \times$ reaction buffer [Invitrogen, Carlsbad, CA]; $0.2 \mathrm{mM}$ each dNTP, $2.0 \mathrm{mM} \mathrm{MgCl}, 0.5 \mathrm{mM}$ each primer, 1.25 unit of Platinum Taq Polymerase [Invitrogen]). Amplifications were carried out in an iCycler thermalcycler (BioRad, Hercules, CA) under the following conditions: denature at $94^{\circ} \mathrm{C}$ for $1 \mathrm{~min} 25 \mathrm{~s}$; then 34 cycles of denature at $93^{\circ} \mathrm{C}$ for $35 \mathrm{~s}$, anneal at $62^{\circ} \mathrm{C}$ for $55 \mathrm{~s}$, extend at $72^{\circ} \mathrm{C}$ for $50 \mathrm{~s}$, adding $5 \mathrm{~s}$ at each cycle; and a final extension at $72^{\circ} \mathrm{C}$ for $10 \mathrm{~min}$. Ramp rate was $3.3^{\circ} \mathrm{C} / \mathrm{s}$ heating and $2.0^{\circ} \mathrm{C} / \mathrm{s}$ cooling.

Products from the first amplification were diluted 1/500 in ultrapure water, then subjected to the second amplification using primer set Phyto2/Phyto3, using either a real-time or conventional PCR method. For real-time amplification, an aliquot of $6.25 \mu \mathrm{l}$ of each dilution was included in each $25.00-\mu$ reaction $(1 \times$ reaction buffer [Invitrogen], $0.2 \mathrm{mM}$ each dNTP, $3.0 \mathrm{mM} \mathrm{MgCl}, 10^{-5} \times$ SYBR green [Sigma-Aldrich, St. Louis], $10^{-5} \times$ flourescein [BioRad], $0.5 \mathrm{mM}$ each primer, 0.75 unit of Platinum Taq Polymerase [Invitrogen]).

Real-time second round amplifications were carried out in an iCycler IQ real-time capable thermalcycler (Bio-Rad) using the protocol as described for first-round amplification. Real-time data were collected during the extension step. Immediately following amplification, product melt temperatures $\left(\mathrm{T}_{\mathrm{m}}\right)$ were determined with the following conditions: 110 cycles at $62^{\circ} \mathrm{C}$ for $10 \mathrm{~s}$, adding $0.3^{\circ} \mathrm{C}$ at each cycle (melt curve, data collection step). Ramp rate was $3.3^{\circ} \mathrm{C} / \mathrm{s}$ heating and $2.0^{\circ} \mathrm{C} / \mathrm{s}$ cooling. Unless otherwise specified, this real-time, nested protocol was used in all tests here described.

The protocol for the second round of conventional PCR was as for real-time, but with reaction reagents and conditions exactly the same as for the Phyto1/Phyto4 amplification. Products were visualized using agarose gel electrophoresis (1.3 to $1.5 \%$ agarose in $0.5 \times$ Tris-borate EDTA buffer).

Positive and negative controls. To ascertain that DNA extractions were successful, universal primers were developed in the 28S region of the rDNA, 1,909 bp from the Phyto1/Phyto4 amplicon. To determine the expected fragment size, the primers were aligned against all available complete large subunit rDNA sequences for organisms within the same genera as the pathogen and its known hosts: P. megasperma (GenBank accession no. X75631.1), Quercus suber (GenBank accession no. AY428812.1), and Aesculus pavia (GenBank accession no. AF479138.1). It was confirmed that this primer set could amplify its target simultaneously with the Phyto1/Phyto4 and Phyto2/Phyto3 primers, without interference (data not shown). Reaction parameters for both first and second rounds are as previously described, with the addition of $0.5 \mathrm{mM}$ of each $28 \mathrm{~S}$ primer to both the first and second rounds of amplification.

A minimum of one negative water control was included with each PCR run. Ultrapure water was added to the reaction well in place of DNA template before the first amplification. Afterward, this control was treated identically to the unknown samples; it was diluted, then subjected to the second amplification. For the environmental screen, each 96-well plate included a minimum of 16 such water controls. Any plate in which positive results were observed in a water control was considered contaminated and the results discarded.

Several precautions were taken to avoid DNA contamination of plant samples and PCR reactions. All amplified products were segregated spatially from other laboratory functions, and never introduced into the area in which first-round PCR was prepared. All first-round PCR reactions were set up in either a laminar flow hood (cleaned thoroughly with DNA-Away [Molecular BioProducts Inc., San Diego, CA] before use) or a plexiglass box that had been subjected to 15 min of germicidal UV radiation. Secondround PCR cocktails were prepared and aliquotted in the laminar flow hood or the plexiglass box, then removed to the high-DNA area before template was added. Separate sets of pipettes were maintained for amplified products, low-concentration DNA, and DNA-free applications. Aerosol-resistant pipette tips were used at all times.

Amplicons from 26 plant samples were sequenced to confirm pathogen identity, including an isolate from each newly discovered host. PCR products (obtained through conventional nested PCR as outlined above) were cleaned via QiaQuick PCR Purification kit (Qiagen, Qiagen Sciences, MD), as per kit instructions, except that cleaned products were eluted in $30 \mu \mathrm{l}$ of salt-free water. Cleaned products were cycle-sequenced with $4 \mu \mathrm{l}$ of Big Dye Terminator (version 3.0; Applied Biosystems, Foster City, CA), 2.4 pmol of salt-free primer, and 5 to $20 \mathrm{ng}$ of DNA (template concentration determined by gel). Cycle-Sequencing was performed on a thermalcycler (Bio-Rad iCycler) according to ABIrecommended protocol. Samples were de-salted in ethanol as per ABI instructions (ABI Prism 3100 Genetic Analyzer Sequencing Chemistry Guide). Samples were brought up in $10 \mu \mathrm{l}$ of $\mathrm{Hi}-\mathrm{Di}$ Formimide (Applied Biosystems) and denatured on a thermocycler $\left(95^{\circ} \mathrm{C}\right.$ for $5 \mathrm{~min}$, followed by a hold at $\left.4^{\circ} \mathrm{C}\right)$. Capillary electrophoresis was performed on an ABI Prism 3100 Genetic Analyzer, with POP-4 polymer on a $36-\mathrm{cm}$ capillary array, and data were collected on Data Collection Software (version 1.0) and analyzed with Sequencher (version 4.1.2; Gene Codes Corporation, Ann Arbor, MI).

Season and plant substrate. To corroborate the apparent effects of plant substrates and season on detection frequency of $P$. ramorum, the PCR assay was run on a total of 424 samples, all additional to samples included in the disease survey. All 424 were obtained from plants from which $P$. ramorum previously had been isolated by culture.

In order to investigate the effect of season on the PCR-based diagnostic assay, 299 samples of exudates from bark cankers on oak and tanoak in Santa Cruz County, CA were collected periodically from March 2001 until February 2002. P. ramorum had been successfully isolated from cambium taken from the cankers on

TABLE 1. Sequences of primers used for amplification of Phytophthora ramorum and hosts

\begin{tabular}{llc}
\hline Name & \multicolumn{1}{c}{ Sequence 5' to 3' } & Amplicon size (bp) \\
\hline Phyto1 & CATGGCGAGCGCTTGA & 687 \\
Phyto4 & GAAGCCGCCAACACAAG & \\
Phyto2 & AAAGCCAAGCCCTGCAC & 291 \\
Phyto3 & GGTGGATGGGGACGTG & 917 \\
ITS1 $^{\mathrm{a}}$ & TCCGTAGGTGAACCTGCGG & \\
ITS4 $^{\mathrm{a}}$ & TCCTCCGCTTATTGATATGC & $194^{\mathrm{b}}$ \\
28SF & GGAACGTGAGCTGGGTTTAG & $191^{\mathrm{c}}$ \\
28SR & TTCTGACTTAGAGGCGTTCAG & \\
\hline
\end{tabular}

${ }^{a}$ From White et al. (48).

${ }^{\mathrm{b}}$ For Phytophthora ramorum.

${ }^{\mathrm{c}}$ For plant hosts. 
each of the selected trees. Exudates were processed as described above for plant tissue, and assayed both by PCR and culturing. Results were compared among collections obtained during the three seasonal categories described above.

PCR assays to compare efficacy on different host substrates were performed on a subset of 204 samples. The substrates tested included leaves from bay laurel, leaves from hosts other than bay laurel, oak wood, and exudates from bark cankers. Collections and PCR assays were all performed in what we understand to be the most favorable period of the year for detection of $P$. ramorum (March to June). Results from 2001 and 2002 were pooled for this analysis.

Specificity and sensitivity. Cultures of $P$. ramorum and of 20 additional Phytophthora spp. (Table 2) were grown in either potato dextrose or pea broth for 7 to 10 days, then filtered and lyophilized. The DNA of three P. cambivora isolates (NY217, 444, and NY249) was extracted from mycelia taken from 110-mm rye agar plates. The plates were microwaved on $50 \%$ power for $30 \mathrm{~s}$ with the cover on. The mycelia then were blotted on clean paper towels, transferred back to the original plate, and microwaved on $50 \%$ power for an additional 6 to $8 \mathrm{~s}$. The mycelia were blotted again on clean paper towels until all melted agar was removed, then frozen and lyophilized.

Specificity of amplification was tested on DNA extracted from the pure cultures using PCR parameters as described and additionally using $\mathrm{MgCl}_{2}$ at $1.5 \mathrm{mM}$ in the first amplification round. Extracts were diluted 1/1,000 in ultrapure water before being amplified. To insure the presence of DNA, all extracts had been successfully amplified using the universal primers ITS1/ITS4 (Table 1) (48).

The specificity of amplicon melt temperature was determined in a series of steps. First, six replicates of pure-culture DNA extracts from 18 isolates of 15 species (Table 2) were amplified with the universal primers ITS1/ITS4 (parameters as described for Phyto1/Phyto4 first-round amplification). Products then were diluted 1:500 and amplified with the primer set Phyto2/Phyto3 under relaxed conditions, in order to allow amplification of sequences that did not exactly match the primers. Parameters were as previously described, except that the annealing temperature was at $56^{\circ} \mathrm{C}$, and $\mathrm{MgCl}_{2}$ was at $3.5 \mathrm{mM}$. Melt temperatures $\left(\mathrm{T}_{\mathrm{m}}\right)$ were compared among all successful amplicons using Tukey's honestly significantly different test with $\alpha$ at 0.05 (JMP version 5.01; SAS Institute, Cary, NC).

A minimum DNA detection threshold was determined for $P$. ramorum and $P$. lateralis by testing a 10 -fold dilution series of known DNA concentration. DNA extracts initially were tested at concentrations on the order of $10 \mathrm{ng} / \mu \mathrm{l}$; the concentration was decreased until no products could be observed by either real-time PCR or agarose gels. To compare sensitivity of the nested protocol, as opposed to amplification by Phyto1/4 alone, a subset of plant samples were screened with nested PCR (real-time protocol). A total of 159 samples of exudates, foliar and wood tissue from symptomatic plants putatively infected with $P$. ramorum, were included in the comparative analysis. Products were visualized with agarose gels after both first and second rounds. In addition, the final products were visualized with real-time PCR. Results from the full-nested assay were compared with those from the single Phyto1/Phyto4 run.

Quantification of pathogen DNA. Real-time PCR can be used to quantify starting concentrations of DNA by the threshold cycle $(\mathrm{Ct})$, the amplification cycle at which the concentration of DNA produced in the PCR reaction climbs above a baseline, as visualized by fluorescence (51). To determine whether $\mathrm{Ct}$ corresponded to viability, symptomatic leaves of $U$. californica were collected from Big Sur, CA in April and May 2002. Leaf pieces were plated on PARP selective media, and the remaining leaf tissue was frozen. Bulk DNA was extracted from the tissue as described above, and the samples were screened for $P$. ramorum using the nested, real-time protocol. All samples positive for $P$. ramorum were tested again in a single 96 -well plate $(n=51)$ to allow for

TABLE 2. Isolates of Phytophthora spp. used to determine specificity of reaction ${ }^{2}$

\begin{tabular}{|c|c|c|c|c|c|}
\hline Species $^{b}$ & $\begin{array}{l}\text { Local isolate } \\
\text { no. }\end{array}$ & $\begin{array}{l}\text { Alt isolate } \\
\text { no. }\end{array}$ & Host & Origin & $\begin{array}{l}\text { Lowest concentration amplified } \\
\text { (ng DNA/25- } \mu \text { l reaction) }\end{array}$ \\
\hline Phytophthora boehmeriae $\mathrm{PT}$ & MP2 & 325 & Boehmeria nivia & Papua New Guinea & Not cross-amplified \\
\hline P. cactorum $^{\mathrm{PT} *}$ & MP19 & 311 & Pseudotsuga menziesii & Washington & Not cross-amplified \\
\hline P. cambivora $^{\mathrm{PT} *}$ & MP14 & P198513 & Quercus agrifolia & California & Not cross-amplified \\
\hline P. cambivora $^{\mathrm{PT} *}$ & MP22 & $444(\mathrm{~A} 2)$ & Prunus dulcis & California & Not cross-amplified \\
\hline P. cambivora $^{\mathrm{PT}}$ & MP23 & 443 (A1) & P. avium & California & Not cross-amplified \\
\hline P. cambivora $^{\mathrm{PT} *}$ & NY217 & $\ldots$ & Malus domestica & New York & Not cross-amplified \\
\hline P. cambivora $^{\mathrm{PT} *}$ & NY249 & $\ldots$ & M. domestica & Oregon & Not cross-amplified \\
\hline P. capsici $^{\mathrm{PT} *}$ & MP26 & 302 & Capsicum annuит & Florida & Not cross-amplified \\
\hline P. cinnamomi $^{\mathrm{MC} *}$ & P6379(A1) & $\ldots$ & Ananas comosus & Taiwan & Not cross-amplified \\
\hline P. citricola $^{\mathrm{LM} *}$ & MP18 & $\ldots$ & - & California & Not cross-amplified \\
\hline P. cryptogea $^{\mathrm{PT} *}$ & MP11 & 438 & Lycopersicon esculentum & $\ldots$ & Not cross-amplified \\
\hline P. drechsleri ${ }^{\mathrm{LM}}$ & $\ldots$ & $\ldots$ & $\ldots$ & $\ldots$ & Not cross-amplified \\
\hline P. erythroseptica ${ }^{\mathrm{PT} *}$ & MP6 & 355 & Solanum tuberosum & Maine & Not cross-amplified \\
\hline P. gonapodyides $^{\mathrm{PT} *}$ & $\ldots$ & 393 & M. domestica & New York & Not cross-amplified \\
\hline P. hibernalis* & 1895 & $\ldots$ & Aquilegia vulgaris & New Zealand & Not cross-amplified \\
\hline P. hibernalis & 1896 & $\ldots$ & Citrus sinensus & Portugal & Not cross-amplified \\
\hline P. nemorosa & MP16 & $\ldots$ & $\ldots$ & California & Not cross-amplified \\
\hline P. infestans ${ }^{\mathrm{LM}}$ & $\ldots$ & $\ldots$ & - & $\ldots$ & Not cross-amplified \\
\hline$P$. lateralis & $91 / 9 / 9-1$ & $\ldots$ & Chamaecyparis lawsoniana & California & 2.4 \\
\hline P. lateralis* & PL33 & $\ldots$ & C. lawsoniana & California & 0.7 \\
\hline P. megasperma ${ }^{\mathrm{PT} *}$ & MP10 & 309 & Pseudotsuga menziesii & Washington & Not cross-amplified \\
\hline P. megasperma f. sp. glycinea ${ }^{\mathrm{PT}}$ & MP20 & 312 & Glycine $\max$ & Wisconsin & Not cross-amplified \\
\hline P. palmivora ${ }^{\mathrm{PT} *}$ & MP8 & 427 & Theobroma cacao & $\ldots$ & Not cross-amplified \\
\hline P. parasitica $^{\mathrm{PT} *}$ & MP3 & 331 & Nicotiana tabacum & North Carolina & Not cross-amplified \\
\hline P.pseudotsugae $\mathrm{PT}$ & 308 & 308 & P. menziesii & Oregon & Not cross-amplified \\
\hline P. pseudosyringae* & P40 & $\ldots$ & Q. agrifolia & California & Not cross-amplified \\
\hline P. syringae ${ }^{\mathrm{CB}}$ & MP15 & P115773A & Rhododendron spp. & California & Not cross-amplified \\
\hline$P$. ramorum $*$ & Pt102 & $\ldots$ & Q. agrifolia & California & $1.29 \mathrm{E}-6(12.9 \mathrm{fg})$ \\
\hline
\end{tabular}

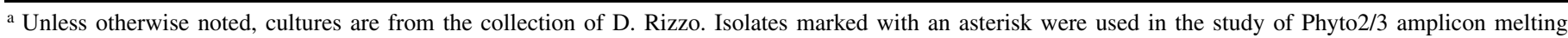
temperature.

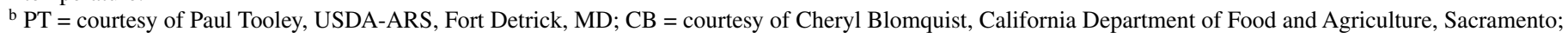
$\mathrm{MC}=$ courtesy of Mike Coffey, University of California, Riverside; and LM = courtesy of Laurence Marais, University of California, Riverside. 
comparison of $\mathrm{Ct}$ among samples. First-round amplifications were duplicated using real-time PCR with SYBR green to allow for the determination of $\mathrm{Ct}$ and to ascertain that first-round products were still in the linear growth phase when amplification was terminated-a prerequisite for quantification with nested real-time PCR (34). Fluorescence baseline and threshold values for the second amplification round were determined automatically, and all wells confirmed positive by a $\mathrm{T}_{\mathrm{m}}$ in the expected range. Cts were compared for samples with positive isolations $(n=21)$ versus samples from which a culture of $P$. ramorum could not be obtained $(n=30)$ using Student's $t$ test. Prediction intervals were calculated by hand (52).

\section{RESULTS}

Statewide disease survey. In the widespread survey of plants suspected of $P$. ramorum infection, we detected infection in 204 of 528 samples tested using the assay presented here. We detected 10 new hosts (Table 3) and four new infected counties (Contra Costa, Humboldt, Mendocino, and Solano Counties) using this method. Of 33 sites in 14 counties, 23 were found to be positive for $P$. ramorum during the exploratory surveys of California. Melt curves of amplified products were used to determine results (mean $\mathrm{T}_{\mathrm{m}} 90.8^{\circ} \mathrm{C}$; range 89.9 to $91.7^{\circ} \mathrm{C}$; standard deviation [SD] $0.3^{\circ} \mathrm{C}$ ). One or more amplicons from each new host were sequenced; all had complete homology to the $P$. ramorum sequence.

The method developed detected $P$. ramorum infection in a number of samples where culturing failed (Figs. 1 and 2; Table 3). PCR results were in accordance with cultural results in 169 of the 216 samples for which the two techniques were compared. For any subset of samples, PCR detection always was more sensitive than direct culturing, although a few individual isolates were positive by culturing and negative by PCR ( 47 samples were positive by PCR detection but not by culturing, versus 4 positive by culturing but not by PCR). In addition, the PCR-based assay detected $P$. ramorum in 72 of 299 canker exudates processed (Fig. $3)$. In contrast, no cultures were isolated from the exudates, even though $P$. ramorum had been isolated from wood tissue within the cankers themselves.

Season and plant substrate. Inspection of the detection frequency in Quercus spp. and L. densiflora canker exudates by the nested PCR technique revealed that detection was most successful during the months of March through June, when California's
Mediterranean climate is warm, yet the rains have not yet stopped for the summer (Fig. 3). This pattern also was observed in detection frequencies of $P$. ramorum throughout the environmental survey; our highest detection frequency from symptomatic foliar and wood tissue was during the months of March through June, when $50 \%$ of samples tested were positive. November through February
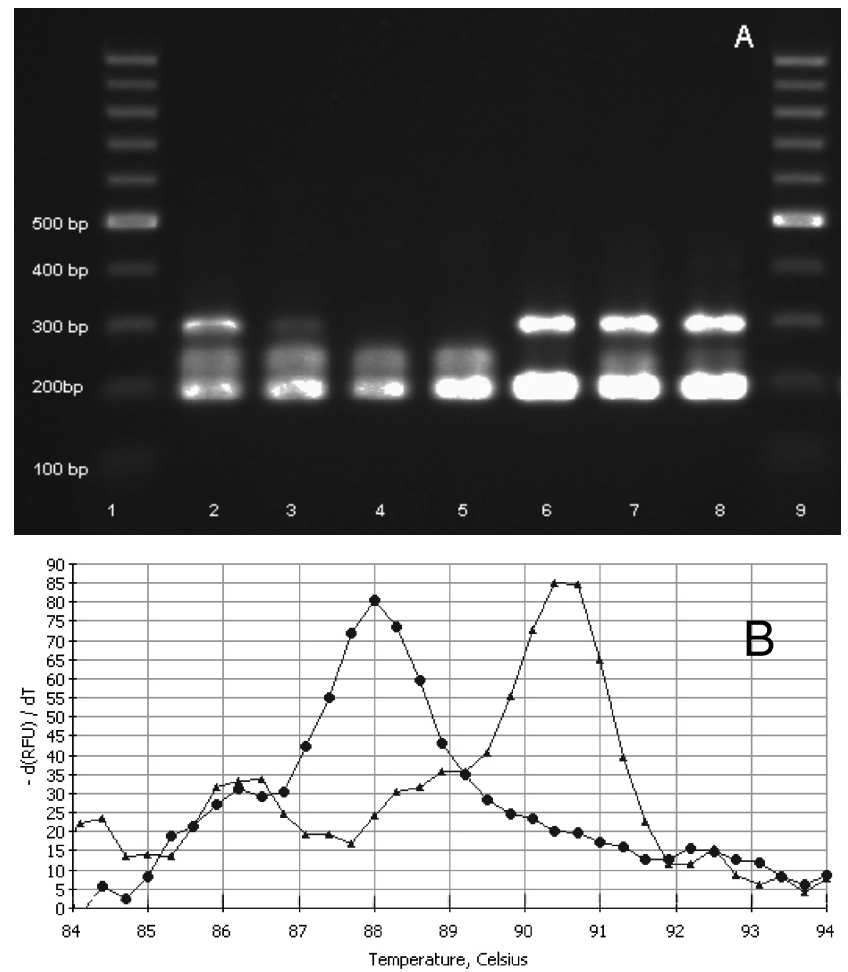

Fig. 1. Detection of Phytophthora ramorum by nested polymerase chain reaction with Phyto and 28S primer sets. The Phyto2/Phyto3 amplicon is $291 \mathrm{bp}$; $28 \mathrm{~S} / 28 \mathrm{~F}$ is at 191 to $194 \mathrm{bp}$. A, results visualized by gel electrophoresis: lanes 1 and 9, 100-bp size standard; lanes 2 to 3, foliar samples positive for $P$. ramorum; lanes 4 to 5 , foliar samples negative for $P$. ramorum, but positive for $28 \mathrm{~S}$, indicating successful DNA extraction; lane $6, P$. ramorum DNA $(0.2 \mathrm{ng} / \mu \mathrm{l})$, lane $7, P$. ramorum DNA $\left(2.6 \times 10^{-3} \mathrm{ng} / \mu \mathrm{l}\right)$; lane $8, P$. ramorum DNA $\left(1.3 \times 10^{-3} \mathrm{ng} / \mu \mathrm{l}\right)$. B, Results visualized by melt temperature, as reflected in flourescence. Circles: foliar sample positive for P. ramorum. Triangles: foliar sample negative for $P$. ramorum, but positive for $28 \mathrm{~S}$.

TABLE 3. Confirmed hosts of Phytophthora ramorum discovered during the California survey, and the method with which they were first detected ${ }^{\mathrm{a}}$

\begin{tabular}{|c|c|c|c|}
\hline Host (common name, species) & Plant part infected & $\begin{array}{l}\text { Detection } \\
\text { method }^{b}\end{array}$ & GenBank accession number \\
\hline Big leaf maple, Acer macrophyllum & Leaves & PCR & $\ldots$ \\
\hline California bay laurel/Oregon myrtle, Umbellularia californica & Leaves & PCR & AY423283-AY423286 \\
\hline California black oak, Quercus kellogii & Main stem & Culture & $\ldots$ \\
\hline California buckeye, Aesculus californica & Branches, leaves & PCR & $\ldots$ \\
\hline Canyon live oak, $Q$. chrysolepis & Main stem, branches, leaves & Culture & $\ldots$ \\
\hline Coast live oak, $Q$. agrifolia & Main stem & Culture & AF521564, AY423276-423278, AY423280 \\
\hline Coast redwood, Sequoia sempervirens & Branches, leaves & PCR & AF521577 \\
\hline Coffeeberry, Rhamnus californica & Branches, leaves & PCR & $\ldots$ \\
\hline Douglas fir, Pseudotsuga menziesii & Branches, leaves & Culture & $\ldots$ \\
\hline Evergreen huckleberry, Vaccinium ovatum & Main stem, branches, leaves & Culture & $\ldots$ \\
\hline Honeysuckle, Lonicera hispidula & Branches, leaves & PCR & $\ldots$ \\
\hline Manzanita, Arctostaphylos manzanita & Branches, leaves & PCR & $\ldots$ \\
\hline Ornamental rhododendron, Rhododendron sp. 1 & Branches, leaves & Culture & AY423279, AF521567 \\
\hline Pacific madrone, Arbutus menziesii & Branches, leaves & PCR & $\ldots$ \\
\hline Rhododendron, Rhododendron macrophyllum & Branches, leaves & PCR & $\ldots$ \\
\hline Shreve's oak, $Q$. parvula var. shrevei & Main stem & Culture & $\ldots$ \\
\hline Tanoak, Lithocarpus densiflora & Main stem, branches, leaves & Culture & AY423281-AY423282 \\
\hline Toyon, Heteromeles arbutifolia & Branches, leaves & PCR & $\ldots$ \\
\hline Western starflower, Trientalis latifolia & Leaves & Culture/PCR & $\ldots$ \\
\hline
\end{tabular}

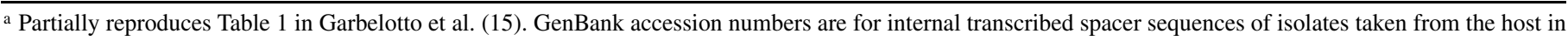
question (23).

b $\mathrm{PCR}=$ polymerase chain reaction. 
and July through August each showed a lower detection frequency, at 36 and $34 \%$, respectively.

Detection levels varied by host: leaves of $U$. californica had the highest frequency based on both PCR and culture detections methods. Wood samples from Quercus spp. and L. densiflora and leaves of hosts other than $U$. californica had an intermediate rate of detection by both methods (Fig. 2). The finding that frequency of successful diagnosis is highly dependent on host and substrate was mirrored by the results of the analysis shown in Figure 4. In this case, samples representative of different substrates all were collected in the spring, the most favorable season for detection of $P$. ramorum. Samples all were known to be infected by the pathogen, because they came from individual trees or plants from which $P$. ramorum had been isolated previously. Again, leaves of $U$. californica represented the substrate with the highest level of detection, whereas canker exudates from $Q$. agrifolia and L. densiflora had the lowest success rate by PCR and were never culturable, even though $P$. ramorum had been isolated from tissue collected from the cankers themselves. (Fig. 4).

Specificity and sensitivity. $P$. lateralis was the only other species among the 20 tested to cross-amplify in the assay. This

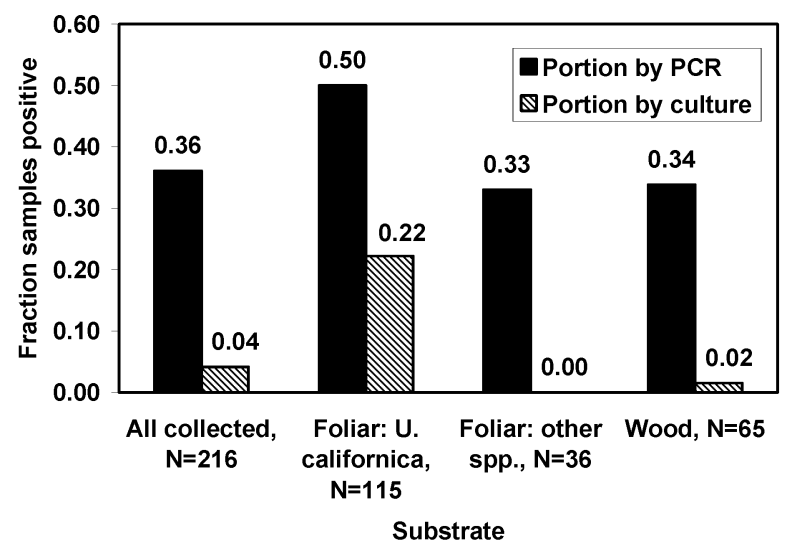

Fig. 2. Frequency of Phytophthora ramorum-positive samples from the statewide survey through either nested polymerase chain reaction (PCR) or direct plating on selective media. All 216 samples shown here initially failed to produce a culture. Plating data shown here refers to the results of a second culturing attempt.

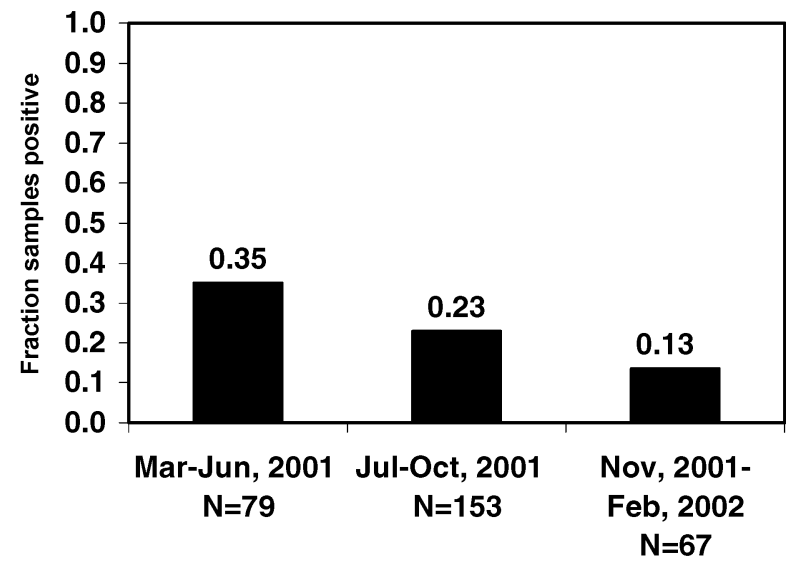

Collection date

Fig. 3. Frequency of positive results by nested polymerase chain reaction by season. Data represent canker exudates from oak species and tanoak sampled repeatedly over the course of a year. These trees were known infected with Phytophthora ramorum, because the pathogen had been isolated from wood tissue taken from cankers. Groupings were determined by temperature and rainfall, and correspond to expectations of periods of greater or lesser pathogen growth and sporulation. occurred only at high DNA concentrations (Table 2). In contrast, $P$. ramorum could be detected at concentrations as low as $12 \mathrm{fg}$. Results were the same whether first-round amplification was at $1.5 \mathrm{mM}$ or $2.0 \mathrm{mM} \mathrm{MgCl}$. P. cambivora previously has been reported to be cross-amplified by this primer set (9). However, sequencing revealed the product of the isolate previously amplified by our lab to be the result of cross-contamination, because the amplified sequence was a complete match for $P$. ramorum. A new extraction of this isolate was not amplified in repeated tests, nor were the other four P. cambivora isolates tested (Table 2). We hypothesize that the original culture, which was isolated from $Q$. agrifolia suspected of harboring P. ramorum, actually was mixed, and contained both pathogens. If this original culture had been predominantly $P$. cambivora (as it was morphologically identified), the traces of $P$. ramorum may have been removed as the culture was sequentially passed through plates.

Four Phytophthora spp. were amplified by Phyto2/Phyto3, from ITS1/ITS4 amplicons (note that this does not represent cross-reactivity of our diagnostic method; the first-round primer set is different and PCR conditions were relaxed to enhance reactivity). Of these, $P$. lateralis and $P$. erythroseptica were indistinguishable from $P$. ramorum by $\mathrm{T}_{\mathrm{m}}\left(P\right.$. ramorum mean $\mathrm{T}_{\mathrm{m}}$ $90.3^{\circ} \mathrm{C}$, SD $0.21^{\circ} \mathrm{C} ;$ P. lateralis mean $\mathrm{T}_{\mathrm{m}} 90.0^{\circ} \mathrm{C}$, SD $0.31^{\circ} \mathrm{C}$; P. erythroseptica mean $\mathrm{T}_{\mathrm{m}} 90.4^{\circ} \mathrm{C}, \mathrm{SD} 0.35^{\circ} \mathrm{C}$ ), but $P$. hibernalis had a significantly lower $\mathrm{T}_{\mathrm{m}}$ (mean $\mathrm{T}_{\mathrm{m}} 88.8^{\circ} \mathrm{C}, \mathrm{SD} 0.25^{\circ}$ ), and $P$. cryptogea's was significantly higher (mean $\mathrm{T}_{\mathrm{m}} 91.0^{\circ} \mathrm{C}, \mathrm{SD}$ $\left.0.12^{\circ} \mathrm{C}\right)$.

Detection of $P$. ramorum in the 159 plant samples of unknown infection status increased from 23 in the first round of PCR to 77 after both rounds. Positives as determined by agarose gel electrophoresis after the final PCR all were identical to those as determined by product melt curves through real-time PCR.

Quantification of pathogen DNA. In testing $\mathrm{Ct}$ by viability, culture-positive symptomatic samples had lower $\mathrm{Ct}$ values than did culture-negative samples (culture-positive: mean Ct 13.15, SD 3.71, range 1.6 to 17.3; culture-negative: mean $\mathrm{Ct} 15.43$, SD 3.71, range 9.5 to 22.6 ; $t$ test, $P=0.033$ ). Variances were equal in each group (O'Brien test, $P=0.89$ ). The prediction interval for culture-positive samples was 5 to 21 , compared with 8 to 23 for culture-negative samples.

\section{DISCUSSION}

The method presented here was instrumental in the early stages of research on SOD in California. This technique allowed us to confirm $P$. ramorum infection in over 204 symptomatic plant

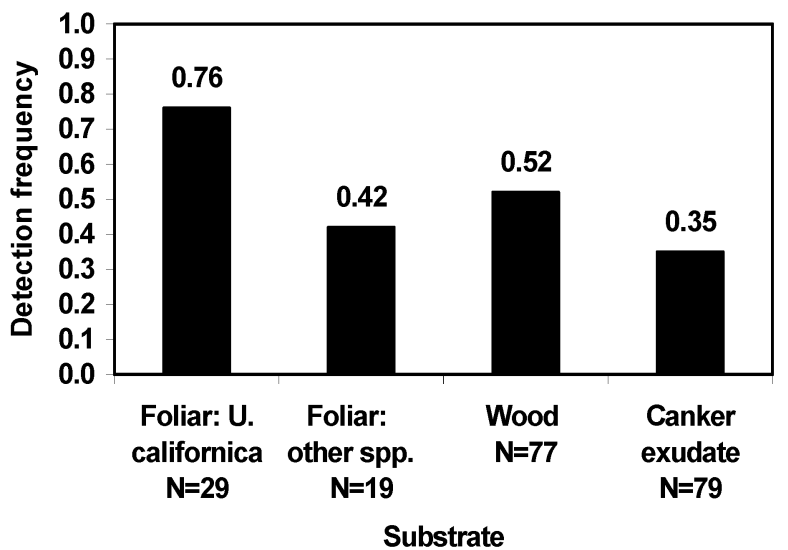

Fig. 4. Frequency of Phytophthora ramorum-positive plant samples through nested polymerase chain reaction, according to substrate from which DNA was extracted. Individual hosts previously were determined to be infected though positive isolations. All samples were taken between March and June, in the years 2001 and 2002. 
samples from 33 California sites, and allowed us to expand the confirmed host range of $P$. ramorum by 10 hosts and four California counties far sooner than if identification were based on pathogen isolation alone. These surveys were designed to rapidly provide information on overall distribution of the newly discovered pathogen. Results from PCR analyses accelerated our understanding of the wide range of symptoms caused by this pathogen. This knowledge, in turn, accelerated our discovery of new hosts by broadening the aim of our collections to include plants displaying novel symptoms.

This was one of the first studies in which basic information, such as host and geographic range, of a new forest disease has been discovered using molecular-based diagnostics. The method described here is sensitive, and the limited cross-reactivity is not expected to interfere with the accuracy of diagnoses from environmental samples. The amount of $P$. lateralis DNA required for amplification is relatively high; in addition, $P$. lateralis has a very limited host range, encompassing only two known species, neither of which is a known host for P. ramorum.

The high sensitivity of the technique is due, in part, to the presence of a large number of copies of ribosomal DNA within each cell. Methods based on molecules not as abundant in the genome inevitably will result in decreased sensitivity. The results indicate that $P$. ramorum DNA concentration in most plants is low and sensitivity is a critical diagnostic issue. Our nested approach based on the multicopy rDNA provides a viable solution. It is common for diagnostic PCR to require a nested design $(1,2)$. Although using nested PCR does open the technique to greater risk of false positive results due to contamination, proper laboratory techniques minimize risk. To maximize detection of false positives due to DNA contamination, we suggest running a number of negative samples equal to the number of positive samples. Negatives, consisting of plant tissue not infected with $P$. ramorum, must be carried through the entire process, including tissue preparation, DNA extraction, dilution, and PCR reactions. Independent corroboration by separate labs should be used to verify critical results. We report here only results from sites from which repeated positive results were obtained, and which eventually were confirmed by isolation of the pathogen. Occasional, unique PCR positives from any given site (i.e., could not be obtained from that site again) were conservatively assumed to be due to laboratory contamination and disregarded. Any given positive result should be able to be replicated by reprocessing the original extracted DNA and, ideally, re-extracting tissue from the same host plant. The latter poses problems, however, if the second sampling is temporally removed from the first. Low frequencies of true, positive results may disappear if a site is later sampled at a time less favorable for pathogen growth.

The multiplex reaction using the Phyto primer sets and the $28 \mathrm{~S}$ primer pair allows differentiation between true negatives (28S amplicon present, Phyto2/3 amplicon absent) and negatives due to failed extractions (28S and Phyto2/3 amplicons absent) (Fig. 1). In our experience, PCR false negatives can result when plant material is processed improperly or DNA extract and first-round amplifications are not stored at constant low temperatures (less than $-20^{\circ} \mathrm{C}$ ).

This study provides some of the first data on seasonality of molecular detection success for $P$. ramorum. The higher detection frequency from March through June likely is due to increased pathogen growth and increased sporulation and infection rates during warm, wet conditions $(8,13)$. The data suggest that surveys for $P$. ramorum are best carried out in late spring, because surveys during the late summer months are likely to underestimate disease abundance, even in known infestation areas.

Two analyses presented in this study (Figs. 2 and 4) indicated that the efficacy of diagnosis both by culturing and PCR was different when dealing with different plant species and substrates. Thus, it seems wise to test the potential sensitivity of the diagnos- tic protocols each time a new host or substrate needs to be assayed, rather than inferring it from results obtained on previously assayed hosts and substrates.

We further describe here a novel nondestructive way of sampling infected oak and tanoak trees. Successful diagnoses were obtained by processing samples of the viscous bleeding caused by $P$. ramorum on oak and tanoak trunks, by collecting the sap on the bark surface without wounding the tree. In contrast, the pathogen was not isolated by culture from any of the exudates, though $P$. ramorum previously had been isolated from wood within the cankers themselves. Nonwounding assays are essential for longterm studies, because the wounds themselves can artificially alter the dynamics of a forest stand by being an infection court for other pathogens or an attraction to insects.

The results of this study indicated that, in the case of "difficult" samples not yielding viable cultures on the first isolation attempt, PCR-based diagnosis was more sensitive than a second isolation attempt (Fig. 2). The use of the molecular assay here described significantly reduced the number of false negative samples: these are samples that, based on culturing alone, would have been regarded as "noninfected". Thus, the nested PCR assay used in this survey is a much more sensitive assay than culturing alone, and its use will improve our ability to detect the pathogen and, hopefully, help us to restrict its movement.

As described elsewhere $(15,40)$, in the absence of successful culturing, PCR-based detection was an integral component in the determination of a new species as a host for $P$. ramorum. The presence of characteristic disease symptoms on a new putative host, multiple independent PCR positives confirmed by sequencing of the amplicon, and successful inoculation studies using isolates from another host were taken as evidence that $P$. ramorum was causing disease on the host in question. It should be noted that in all cases but one (i.e., Manazanita spp.), isolates of $P$. ramorum eventually were obtained from the plant species in question. Subsequently, Koch's postulates were completed to confirm these species as hosts $(13,40)$.

SYBR green-mediated real-time PCR, including melting temperature $T_{m}$ analysis of the final amplicon, does not require gel electrophoresis. Thus, it is faster and more accurate than regular PCR, because melting curves can discriminate among some equally sized amplicons of different sequence. Furthermore, realtime PCR allows for the quantification of the pathogen DNA (4951). Provided that samples in the first PCR round are still in linear growth phase (which may require a reduction in the number of cycles of the first round), the nested technique also can provide some quantification data (34). It then may be possible to distinguish hosts with active, growing infections by the quantity of target DNA present in a given sample. A lower $\mathrm{Ct}$ corresponds to higher DNA concentration in the starting sample. It was observed that viable samples had a lower mean PCR threshold cycle than samples from which cultures were not obtained and, more importantly, that the ranges and prediction intervals of $\mathrm{Ct}$ for culture-positive and culture-negative samples were distinguishable. Thus, if the $\mathrm{Ct}$ value of an additional tested sample falls in a non-overlapping area of the prediction interval, it may be possible to predict whether the sample has a viable infection. For the data set presented, any additional samples with a $\mathrm{Ct}$ falling below 8 would be predicted to be viable, whereas sample with Cts above 21 would be predicted to be nonviable. Any sample falling between 8 and 21 (i.e., the interval in which the range of viable samples and samples from which cultures were not obtained overlap) would be of undetermined viability. It should be noted that, for this method to have predictive value, sample sizes must be sufficiently large and representative of the target population. The prediction interval is a more conservative marker than the range, because it takes into account uncertainty as to where any new data points are likely to fall—extending the area of overlap between culture-positive and culture-negative results. 
The method described in this article has the advantage of being available to laboratories without real-time PCR capacity. Rather than using SYBR and melting temperatures of final amplicons, products can be analyzed through agarose electrophoresis. The technique is equally sensitive for both the European and the North American populations of the pathogen $(25,29)$. The broad applicability of this technique makes it a valid and useful diagnostic tool. The method has been evaluated in the United States by USDA-APHIS and by the Dutch Plant Protection agency, and has been approved in both the United States and the Netherlands as a diagnostic tool to be used by the respective regulatory agencies $(25,29)$.

In conclusion, this method of detection has proven to be effective in the field for the study of an emerging plant disease. The PCR assay described has been responsible for the discovery of new hosts and infested counties, sometimes months before the pathogen was successfully isolated from those areas. This protocol has been of critical importance in developing our understanding of SOD in California and shows that an integrated approach using traditional plant pathology and molecular diagnostics is essential when studying a new pathogen causing a variety of symptoms on a broad range of hosts.

\section{ACKNOWLEDGMENTS}

This research has been supported by grants from the Gordon and Betty Moore Foundation, the California Department of Food and Agriculture, and the USDA Forest Service, Pacific Southwest Region. We thank C. Blomquist, M. Coffey, L. Marais, and P. Tooley for providing cultures; D. Chambers and S. Tjosvold for exudate samples; K. Ivors for contributing DNA extracts, sequences, and helpful discussion; J. Davidson, T. Harnik, M. Mejía-Chang, G. Slaughter, and M. A. Smith for technical assistance; and J. Correll, R. Warner, and two anonymous reviewers for helpful comments

\section{LITERATURE CITED}

1. Bertolini, E., Olmos, A., Martínez, M. C., Gorris, M. T., and Cambra, M. 2001. Single-step multiplex RT-PCR for simultaneous and colourimetric detection of six RNA viruses in olive trees. J. Virol. Methods 96:33-41.

2. Bonants, P., Hagenaar-de Weerdt, M., van Gent-Pelzer, M., Lacourt, I., Cooke, D., and Duncan, J. 1997. Detection and identification of Phytophthora fragariae Hickman by the polymerase chain reaction. Eur. J. Plant Pathol. 103:345-355.

3. Brasier, C. M. 1992 Evolutionary biology of Phytophthora: I. Genetic system, sexuality and the generation of variation. Annu Rev. Phytopathol. 30:153-170.

4. Brasier, C. 2003. Sudden Oak Death: Phytophthora ramorum exhibits transatlantic differences. Mycol. Res. 107:258-259.

5. California Department of Water Resources, Division of Flood Management. 2001. $2001 \mathrm{WY}$ monthly precipitation (all stations) provided by the California Cooperative Snow Surveys: For the period Oct 1, 2000 to Sep 30, 2001. California Data Exchange Center. Online publication.

6. California Department of Water Resources, Division of Flood Management. 2002. 2002 WY monthly precipitation (all stations) provided by the California Cooperative Snow Surveys: For the period Oct 1, 2001 to Sep 30, 2002. California Data Exchange Center. Online publication.

7. Cooke, D. E. L., Drenth, A., Duncan, J. M., Wagels, G., and Brasier, C. M. 2000. A molecular phylogeny of Phytophthora and related Oomycetes. Fungal Genet. Biol. 30:17-32.

8. Davidson, J. M., Rizzo, D. M., Garbelotto, M., Tjosvold S., and Slaughter, G. W. 2002. Phytophthora ramorum and sudden oak death in California: II. Pathogen transmission and survival. Pages 741-749 in: Fifth Symp. Calif. Oak Woodlands. R. Standiford and D. McCreary, eds. USDA For. Serv. Gen. Tech. PSW-GTR-184.

9. Davidson, J. M., Werres, S., Garbelotto, M., Hansen, E. M., and Rizzo, D. M. 2003. Sudden oak death and associated diseases caused by Phytophthora ramorum. Plant Health Progress. Online publication doi:10.1094/ PHP-2003-0707-01-DG.

10. De Merlier, D., Chandeliar, A., and Cavalier, M. 2003. First report of Phytophthora ramorum on Viburnum bodnantense in Belgium. Plant Dis. 87:203.

11. Erwin, D. C. 1983. Variability within and among species of Phytophthora. Pages 149-165 in: Phytophthora: Its Biology, Taxonomy, Ecology, and Pathology. D. C. Erwin, S. Bartnicki-Garcia, and P. H. Tsao, eds. The American Phytopathology Society, St. Paul, MN.

12. Gallegly, M. E. 1983. New criteria for classifying Phytophthora and critique of existing approaches. Pages 167-172 in: Phytophthora: Its Biology, Taxonomy, Ecology, and Pathology. D. C. Erwin, S. BartnickiGarcia, and P. H. Tsao, eds. The American Phytopathology Society, St. Paul, MN.

13. Garbelotto, M., Davidson, J. M., Ivors, K., Maloney, P. E., Hüberli, D., Koike, S. T., and Rizzo, D. M. 2003. Non-oak native plants are main hosts for the sudden oak death pathogen in California. Calif. Agric. 57:18-23.

14. Garbelotto, M., Ratcliff, A., Bruns, T. D., Cobb, F. W., and Otrosina, W. J. 1996. Use of taxon-specific competitive-priming PCR to study host specificity, hybridization, and intergroup gene flow in intersterility groups of Heterobasidion annosum. Phytopathology 86:543-551.

15. Garbelotto, M., Rizzo, D. M., Hayden, K., Mejia-Chang, M., Davidson, J. M., and Tjosvold, S. 2002. Phytophthora ramorum and sudden oak death in California: III. Pathogen genetics. Pages 765-774 in: Fifth Symp. Calif. Oak Woodlands. R. Standiford and D. McCreary, eds. USDA Forest S. Gen. Tech. PSW-GTR-184.

16. Gardes, M., and Bruns, T. D. 1993. ITS primers with enhanced specificity for basidiomycetes - application to the identification of mycorrhizae and rusts. Mol. Ecol. 2:113-118.

17. Gonthier, P., Garbelotto, M., and Nicolotti, G. 2003. Swiss stone pine trees and spruce stumps represent an important habitat for Heterobasidion spp. in subalpine forests. For. Pathol. 33:191-203.

18. Gundersen, D. E., and Lee, I. M. 1996. Ultrasensitive detection of phytoplasmas by nested-PCR assays using two universal primer pairs. Phytopathol. Mediterr. 35:144-151.

19. Hansen, E. M., Reeser, P. W., Sutton, W., Winton, L. M., and Osterbauer N. 2003. First report of A1 mating type of Phytophthora ramorum in North America. Plant Dis. 87:1267.

20. Hansen, E. M., and Sutton, W. 2002. Log inoculations to assess tree susceptibility to sudden oak death. (Abstr.) Phytopathology 92:S33.

21. Hüberli, D., Reuther, K. D., Smith, A., Swain, S., Tse, J. G., and Garbelotto, M. 2004. First report of foliar infection of Rosa gymnocarpa by Phytophthora ramorum. Plant Dis. 88:430.

22. Hüberli, D., Van Sant-Glass, W., Tse, J. G., and Garbelotto, M. 2003. First report of foliar infection of starflower by Phytophthora ramorum. Plant Dis. 87:599.

23. Ivors, K. L., Bonants, P. J. M., Rizzo, D. M., and Garbelotto, M. 2004. AFLP and phylogenetic analyses of North American and European populations of Phytophthora ramorum. Mycol. Res. 108:378-392.

24. Kong, P., Hong, C., Jeffers, S. N., and Richardson, P. A. 2003. A speciesspecific polymerase chain reaction assay for rapid detection of Phytophthora nicotianae in irrigation water. Phytopathology 93:822-831.

25. Kox, L., DeGruyter, H., Garbelotto, M., Van Brouwershaven, I., Admiraal, J., and Baayen, R. 2002. Validation of a PCR method for detection and identification of Phytophthora ramorum. (Abstr.) Online. Sudden Oak Death Science Symposium: The State of our Knowledge. Monterey, CA.

26. Lane, C. R., Beales, P. A., Hughes, K. J. D., Griffin, R. L., Munro, D., Brasier, C. M., and Webber, J. F. 2002. First outbreak of Phytophthora ramorum in England, on Viburnum tinus. Online, New Dis. Rep. 6.

27. Lee, I. M., Gundersen, D. E., Hammond, R. W., and Davis, R. E. 1994 Use of mycoplasmalike organisms (MLO) group specific oligonucleotide primers for nested PCR assays to detect mixed-MLO infections in a single host plant. Phytopathology 84:559-566.

28. Lee, S. B., and Taylor, J. W. 1992. Phylogeny of five fungus-like Protoctistan Phytophthora species, inferred from the Internal Transcribed Spacers of Ribosomal DNA. Mol. Biol. Evol. 9:636-653.

29. Levy, L., and Mavrodieva, V. 2003. Evaluation of the PCR detection and DNA isolation methods for use in the Phytophthora ramorum National Pilot Survey. Online, National Agricultural Pest Information System.

30. Linderman, R. G., Parke, J. L., and Hansen, E. M. 2002. Relative virulence of Phytophthora species, including the sudden oak death pathogen $P$. ramorum, on several ornamental species. (Abstr.) Phytopathology 92:S47.

31. Martin, F. M., and Tooley, P. W. 2003. Phylogenetic relationships among Phytophthora species inferred from sequence analysis of mitochondrially encoded cytochrome oxidase I and II genes. Mycologia 95:269-284.

32. Moralejo, E., and Werres, S. 2002. First report of Phytophthora ramorum on Rhododendron sp. in Spain. Plant Dis. 86:1052.

33. Murphy, S. K., and Rizzo, D. M. 2003. First report of Phytophthora ramorum on canyon live oak in California. Plant Dis. 87:315.

34. Nakao, M., Janssen, J. W., Flohr, T., and Bartram, C. R. 2000. Rapid and reliable quantification of minimal residual disease in acute lymphoblastic leukemia using rearranged immunoglobulin and T-cell receptor loci by LightCycler technology. Cancer Res. 60:3281-3289.

35. Orlikowski, L. B., and Szukta, G. 2002. Phytophthora ramorum sp. nov., a new species in Poland recovered from Rhododendron. Phytopathol. Polonica 25:69-79. 
36. Parke, J. L., Lindermann, R. G., and Hansen, E. M. 2002. Susceptibility of Vacinnium to Phytophthora ramorum, cause of sudden oak death. (Abstr.) Phytopathology 92:S63.

37. Ririe, K. M., Rasmussen, R. P., and Wittwer, C. T. 1997. Product differentiation by analysis of DNA melting curves during the polymerase chain reaction. Anal. Biochem. 245:154-160.

38. Rizzo, D. M., and Garbelotto, M. 2003. Sudden oak death: Endangering California and Oregon forest ecosystems. Front. Ecol. Environ. 1:197204.

39. Rizzo, D. M., Garbelotto, M., Davidson, J. M., Slaughter, G. W., and Koike, S. T. 2002. Phytophthora ramorum as the cause of extensive mortality of Quercus spp. and Lithocarpus densiflorus in California. Plant Dis. 86:205-214.

40. Rizzo, D. M., Garbelotto, M., Davidson, J. M., Slaughter, G. W., and Koike, S. T. 2002. Phytophthora ramorum and sudden oak death in California: I. Host relationships. Pages 733-740 in: Fifth Symp. Calif. Oak Woodlands. R. Standiford and D. McCreary, eds. USDA Forest S. Gen. Tech. PSW-GTR-184.

41. Tajima, K., Aminov, R. I., Nagamine, T., Matsui, H., Nakamura H., and Bennoy, Y. 2001. Diet-dependent shifts in the bacterial population of the rumen revealed with real-time PCR. Appl. Environ. Microbiol. 67:27662774.

42. Tooley, P. W., and Englander, L. 2002. Infectivity of Phytophthora ramorum on selected Ericaceous host species. (Abstr.) Phytopathology 92:S81.

43. USDA Animal Plant Health Inspection Service. 2002. Phytophthora ramorum; Quarantine and regulations. 7 CFR Part 301 Federal Register 67(31):6827-6837
44. USDA Animal Plant Health Inspection Service. 2004. Sudden oak death: Phytophthora ramorum. Pest Detection and Management Programs. Online publication.

45. Werres, S., Marwitz, R., Man In't Veld, W. A., De Cock, A. W. A. M., Bonants, P. J. M., De Weerdt, M., Themann, K., Ilieva, E., and Baayen, R. P. 2001. Phytophthora ramorum sp. nov., a new pathogen on Rhododendron and Viburnum. Mycol. Res. 105:1155-1165.

46. Werres, S., and De Meerlier, D. 2003. First detection of Phytophthora ramorum mating type A2 in Europe. Plant Dis. 87:1266.

47. Wetzel, T., Candresse, T., Macquaire, G., Ravelonadro, M., and Dunez, J. 1992. A highly sensitive immunocapture polymerase chain reaction method for plum pox polyvirus detection. J. Virol. Methods 39:27-37.

48. White T. J., Bruns, T., Lee, S., and Taylor, J. 1990. Amplification and direct sequencing of fungal ribosomal RNA genes for phylogenetics. Pages 315-322 in: PCR Protocols: A Guide to Methods and Applications. M. A. Innis, ed. Academic Press, San Diego, CA.

49. Winton, L. M., Manter, D. K., Stone, J. K., and Hansen, E. M. 2003 Comparison of biochemical, molecular, and visual methods to quantify Phaeocryptopus gaeumannii in Douglas-Fir foliage. Phytopathology 93:121-126.

50. Winton, L. M., Stone, J. K., Watrud, L. S., and Hansen, E. M. 2002. Simultaneous one-tube quantification of host and pathogen DNA with real-time polymerase chain reaction. Phytopathology 92:112-116.

51. Wittwer, C. T., Herrmann, M. G., Moss, A. A., and Rasmussen, R. P. 1997. Continuous fluorescence monitoring of rapid cycle DNA amplification. BioTechniques 22:130-138.

52. Zar, J. H. Biostatistical Analysis, 4th ed. Prentice Hall, Upper Saddle River, NJ. 